\title{
Orchidftgri
}

Vol. 1, No. 1, Bulan Februari Tahun 2021

DOI: http://dx.doi.org/10.35138/orchidagri.v1.i1.251

\section{Faktor Sosial Dan Ekonomi Yang Mempengaruhi Partisipasi Anggota Kelompok Wanita Tani Jahe Merah (Zingiber officinale) \\ (Suatu Kasus Pada Anggota Kelompok Wanita Tani Fardurawat Kecamatan Jatiwangi Kabupaten Majalengka)}

\section{Social and Economic Factors Affecting the Participation of Members of the Red Ginger Farmers Group (Zingiber officinale). \\ (A Case in the Members of the Farmer Women Group in Jatiwangi District, Majalengka District).}

\section{RAHMAT MAULANA. I. M', DETY SUKMAWATI' ${ }^{2}$, KARYANA ${ }^{2}$}

${ }^{1}$ Mahasiswa Magister Agribisnis Fakultas Pertanian Universita Winaya Mukti ${ }^{2}$ Dosen Program Studi Magister Agribisnis Fakultas Pertanian Universitas Winaya Mukti Alamat : Jl. Raya Bandung - Sumedang KM 29 Tanjungsari, Telp/Fax: 022-7912585 e-mail :rm52605@gmail.com

\section{ABSTRACT}

(Received: 23-12-21; Published: 20-02-21)

Social and Economic Factors Affecting Participation of Members of the Red Ginger Farmer's Group (Zingiber officinale). The research was conducted in the Fardurawat Farming Women Group, Jatiwangi District, Majalengka Regency. The purpose of this study is to determine: 1). Social factors influence the participation of female farmer group members. 2). Economic factors influence the participation of women farmer group members. and 3). Social and economic factors affect the participation of women farmer group members. The method used in this research is the survey method and the unit of analysis is a member of the group of women farmers in Jatiwangi District, Majalengka Regency and using a sampling technique with the respondent withdrawal technique used in this study is a complete enumeration (census) with a total of 50 respondents. . The collected data were analyzed using path analysis, analytics were adjusted according to the results of hypothesis testing. The results of the study provide the following results: 1) Social factors have an effect on the participation of KWT members, thus social factors have a direct effect of $47.88 \%$ and the influence through a correlative relationship with economic factors is $15.21 \%$ so that the total effect of social factors on KWT member participation is 63, 09\%. 2) Economic factors affect the participation of KWT members. Economic factors have a direct effect of $69.2 \%$ and the effect through a correlative relationship with social factors is $15.21 \%$, so that the total effect of economic factors on KWT member participation is 22.13\%. 3) Social factors and economic factors simultaneously have a significant effect on KWT member participation by $85.22 \%$. The remaining $14.78 \%$ is influenced by other factors not examined in this study. Keywords: Economic Factors, Member Participation of Farmer Women's Groups, Social Factors.

\section{ABSTRAK}

Faktor Sosial dan Ekonomi Yang Mempengaruhi Partisipasi Anggota Kelompok Wanita Tani Jahe Merah (Zingiber officinale). Penelitian dilaksanakan di Kelompok Wanita Tani Fardurawat Kecamatan Jatiwangi Kabupaten Majalengka. Tujuan penelitian ini adalah untuk mengetahui: 1). Faktor sosial 
mempengaruhi partisipasi anggota kelompok wanita tani. 2). Faktor ekonomi mempengaruhi partisipasi anggota kelompok wanita tani. dan 3). Faktor sosial dan ekonomi mempengaruhi partisipasi anggota kelompok wanita tani. Metode yang digunakan dalam penelitian ini adalah metode survei dan unit analisisnya adalah anggota kelompok wanita tani di Kecamatan Jatiwangi Kabupaten Majalengka serta menggunakan teknik pengambilan sample dengan teknik penarikan responden yang digunakan dalam penelitian ini adalah dengan cara pencacahan lengkap (sensus) dengan jumlah responden sebanyak 50 orang. Data yang terkumpul dianalisis dengan menggunakan analisis jalur (Path Analysis), analitik disesuaikan dengan hasil pengujian hipotesis. Hasil penelitian memberikan hasil yaitu: 1) Faktor sosial berpengaruh terhadap partisispasi anggota KWT dengan demikian faktor sosial berpengaruh langsung sebesar 47,88 \% dan pengaruh melalui hubungan korelatif dengan faktor ekonomi $15,21 \%$ sehingga pengaruh total faktor sosial terhadap partisipasi anggota KWT sebesar 63,09 \%. 2) Faktor Ekonomi berpengaruh terhadap partisipasi anggota KWT. Faktor ekonomi berpengaruh langsung sebesar $69,2 \%$ dan pengaruh melalui hubungan korelatif dengan faktor sosial sebesar $15,21 \%$ sehingga pengaruh total faktor ekonomi terhadap partisipasi anggota KWT sebesar 22,13\%. 3) Faktor sosial dan faktor ekonomi secara simultan berpengaruh signifikan terhadap partisipasi anggota KWT sebesar 85,22 \%. Sisanya sebesar 14,78 \% dipengaruhi oleh faktor lain yang tidak diteliti dalam penelitian ini.

Kata Kunci : Faktor Sosial, Faktor Ekonomi, Partisipasi Anggota Kelompok Wanita Tani.

\section{PENDAHULUAN}

Pertanian merupakan sektor yang sangat penting dalam perekonomian nasional. Oleh karena itu, pembangunan ekonomi nasional masih akan tetap berbasis agribisnis. Agribisnis dapat menjadi sumber pertumbuhan ekonomi, penyediaan lapangan pekerjaan, mengembangkan pembangunan daerah serta sebagai sumber devisa negara. Pertanian akan menjadi kekuatan besar jika dikelola secara terpadu dalam satu kesatuan sistem agribisnis. Membangun sistem dan usaha agribisnis yang kokoh berarti pula membangun pertumbuhan sekaligus pemerataan sehingga terjadi keseimbangan antar sektor. Ini juga berarti menciptakan meaningful employment yaitu di luar sektor pertanian, sehingga beban pertanian yang terlalu berat menampung tenaga kerja dapat teratasi (Sukirno, 2012).

Keberadaan kelompok wanita tani diharapkan dapat memfasilitasi antara petani dengan program penyuluhan pertanian yang mempunyai tujuan selaras yaitu peningkatan pendapatan dan kesejahteraan petani. Oleh karena itu pembinaan kelompok wanita tani perlu dilaksanakan secara lebih intensif, terarah dan terencana sehingga mampu meningkatkan peran dan fungsinya (Marzuki, 2001).
Kegiatan pertanian secara umum meliputi kegiatan di bidang bercocok tanam tanaman pangan maupun hortikultura, perikanan, peternakan, perkebunan dan kehutanan. Sektor hortikultura berperan dalam penyediaan gizi dan nutrisi yang terdapat dalam sayursayuran, buah-buahan dan tanaman biofarmaka atau obat-obatan. Salah satu tanaman hortikultura semusim yang memiliki banyak manfaat untuk kesehatan yaitu tanaman biofarmaka atau obat-obatan. Biofarmaka kelompok rimpang merupakan jenis biofarmaka yang paling banyak dibutuhkan sebagai bahan baku pembuatan obat tradisional/jamu oleh berbagai industri baik di dalam negeri maupun di luar negeri. Jahe merupakan salah satu komoditas yang paling banyak dibutuhkan sebagai bahan baku industri obat-obatan tradisional (Siagian, 2014).

Rimpang jahe banyak digunakan sebagai bumbu masak, pemberi rasa dan aroma pada biskuit, permen, kembang gula dan minuman. Jahe juga digunakan pada industri obat, minyak wangi, dan jamu tradisional. Jahe sebagai salah satu tanamanobat dengan klaim khasiat paling banyak, digunakan sebagai bahan baku lebih dari 40 produkobat tradisional sehingga jahe menjadi salah satu tanaman yang dibutuhkan dalam jumlah 
besarun tuk industri kecil obat tradisional (IKOT) maupun industri obat tradisional (IOT) (Kementerian Pertanian, 2008).

Jahe merah (Zingiber officinale) adalah tanaman rimpang yang sangat populer sebagai rempah - rempah dan bahan obat. Rimpangnya berbentuk jemari yang menggembung di ruasruas tengah. Rasa dominan pedas disebabkan senyawa keton bernama zingeron. Jahe merah mempunyai banyak khasiat dan telah lama digunakan sebagai obat tradisional. Khasiat jahe merah antara lain antimual, pereda kejang, anti pengerasan pembuluh darah, anti piretik, anti rematik, penghangat badan. jahe merah juga dapat membunuh bakteri patogen yang merugikan kehidupan manusia. Jahe merah dapat dibuat diolah menjadi jahe merah bubuk, minuman jahe merah instan, asinan jahe, minyak atsiri, oleoresin (Nursal, 2006).

Pasrtisipasi kelompok wanita tani dapat meningkatkan meningkatkan perekonomian dan pengetahuan dalam memanfaatkan lahan dan menjalankan usaha tani lebih meningkat sehingga hasil usaha tani yang diperoleh bisa lebih menutupi kebutuhan keluarga secara maksimal oleh anggota KWT (Alam et al., 2019). Majalengka merupakan suatu daerah yang warganya banyak mengusahatanikan tanaman jahe merah salah satunya di daerah kecamatan jatiwangi. Banyak warga sekitar yang menanam jahe merah dan membentuk suatu kelompok wanita tani (KWT).

Dibentuknya kelompok wanita tani sebagai upaya pelibatan kaum perempuan secara langsung dalam usaha-usaha peningkatan hasil pertanian, serta berpotensi untuk meningkatkan pendapatan dan ketahanan pangan menuju kesejahteraan rumah tangga petani di pedesaan. seperti menjadi bagian dari motivator dalam adopsi dan pengenalan teknologi tani.

Berdasarkan gambaran yang ada dan uraian yang telah dikemukakan, maka penulis tertarik untuk mengadakan penelitian lebih lanjut tentang "Faktor Sosial dan Ekonomi Yang Mempengaruhi Partisipasi Anggota
Kelompok Wanita Tani Jahe Merah (Zingiber officinale)".

Tujuan penelitian ini adalah untuk melakukan wawancara dan observasi mengenai faktor sosial mempengaruhi partisipasi anggota KWT, faktor ekonomi mempengaruhi partisipasi anggota KWT, serta faktor sosial dan faktor ekonomi yang mempengaruhi partisipasi anggota KWT.

\section{METODE PENELITIAN}

Penelitian ini dilakukan di Kelompok Wanita Tani Fardurawat Kampung Wates Desa Jatisura Kecamatan Jatiwangi Kabuapten Majalengka. Waktu penelitian di mulai pada April sampai dengan bulan November 2018. Metode yang digunakan dalam penelitian ini adalah metode Survey.

\section{Jenis dan Sumber Data}

Dalam suatu penelitian diperlukan data yang akurat untuk dilakukan suatu proses analisis. Pengumpulan data dapat dilakukan melalui berbagai cara. Dalam penelitian ini jenis data yang di gunakan adalah data primer dan data sekunder.

1) Data primer merupakan data yang didapat dari sumber pertama seperti hasil dari wawancara atau hasil pengisian kuesioner yang biasa dilakukan oleh peneliti.

2) Data sekunder merupakan data primer yang telah diolah lebih lanjut dan disajikan baik oleh pihak pengumpul data primer atau oleh pihak lain.

\section{Cara Pengumpulan Data}

Dalam suatu penelitian ilmiah, terdapat bebeapa teknik pengumpulan data. Untuk mendapatkan data yang diperlukan dalam penelitian ini, teknik pengumpulan data yang dilakukan yaitu :

1) Kuesioner

Teknik kuesioner merupakan suatu pengumpulan data dengan memberikan atau menyebarkan daftar pertanyaan/pernyataan kepada responden dengan harapan memberikan respon atas daftar pertanyaan tersebut. 
2) Wawancara

Wawancara merupakan salah satu teknik pengumpulan data yang lain. Pelaksanaannya dapat dilakukan secara langsung berhadapan dengan yang diwawancarai, tetapi dapat juga secara tidak langsung seperti memberikan daftar pertanyaan untuk dijawab pada kesempatan lain. Instrumen dapat berupa pedoman wawancara maupun checklist.

\section{Teknik Pengumpulan Data}

Populasi sasaran penelitian ini adalah wanita tani yang mengusahatanikan tanaman jahe merah pada kelompok wanita tani (KWT) di Kecamatan Jatiwangi Kabupaten Majalengka. Dari 16 desa di Kecamatan Jatiwangi hanya satu desa yang mengusahatanikan tanaman jahe merah yaitu terdapat di kelompok wanita tani fardurawat kampung wates desa jatisura yang beranggotakan 50 orang.

Teknik penarikan responden yang digunakan dalam penelitian ini adalah dengan cara pencacahan lengkap (sensus), artinya semua populasi dijadikan sampel. Hal ini didasarkan pada pendapat Suharsimi Arikunto (2006), bahwa apabila populasi kurang dari 100, lebih baik semua populasi dijadikan sampel penelitian.

\section{Rancangan Analisis dan Uji Hipotesis}

Metode statistik yang digunakan untuk menganalisis pengaruh faktor sosial dan ekonomi terhadap partisipasi anggota kelompok wanita tani jahe merah di Kecamatan Jatiwangi Kabupaten Majalengka menggunakan Analisis Jalur (Path Analysis), sehingga terlihat hubungan faktor sosial $\left(\mathrm{X}_{1}\right)$ dan faktor ekonomi $\left(\mathrm{X}_{2}\right)$ sebagai variabel independen terhadap partisipasi anggota kelompok wanita tani jahe merah (Y) sebagai variabel dependen.

\section{Uji Validitas}

Pengujian instrumen dilakukan terlebih dahulu sebelum pengujian data dan pengujian hipotesis, Dalam hal ini perlu dibedakan antara hasil penelitian yang valid dan reliabel dengan instrumen yang valid dan reliabel. Hasil penelitian yang valid bila terdapat kesamaan antara data yang terkumpul dengan data yang sesungguhnya terjadi pada objek yang diteliti. Valid berarti instrumen tersebut dapat digunakan untuk mengukur apa yang seharusnya diukur.

\section{Uji Reliabilitas}

Reliabilitas adalah istilah yang digunakan untuk menunjukan sejauh mana suatu hasil pengukuran relatif konsisten apabila pengukuran pada gejala yang sama diulangi dua kali atau lebih dengan kata lain reliabilitas adalah indeks yang menunjukan sejauh mana suatu alat pengukur dapat dipercaya atau diandalkan. Jika suatu alat ukur di pakai dua kali atau lebih untuk mengukur gejala yang sama dan hasil pengukuran relatif sama dan konsisten, maka alat ukur tersebut reliable. Reliabilitas merupakan salah satu ciri atau karakter utama instrumen pengukuran yang baik. Ide pokok reliabilitas adalah sejauh mana hasil pengukuran dapat dipercaya, yaitusejauh mana skor hasil pengukuran terbebas dari kekeliruan pengukuran (error of measurement).

\section{Pengujian Hipotesis}

Berdasarkan hasil pengumpulan data yang dilakukan dilapangan, maka peneliti mengolah dan menganalisis data sedemikian rupa sehingga dapat menunjukan makna untuk menjawab masalah yang diteliti. Kemudian peneliti dapat menarik beberapa kesimpulan yang tepat terhadap hasil penelitiannya. Analisa data dilakukan setelah data penelitian terkumpul, sebagai berikut :

1) Editing, proses kegiatan penyuntingan data atau menyortir data yang tepat dan benar dengan data-data yang salah dan kosong. Hasilnya adalah data yang baik.

2) Koding, proses pemberian skor/penilaian terhadap hasil responden atau pemberi identitas dengan cara memberikan kode- 
kode pada kategori jawaban responden sehingga memiliki arti tertentu.

3) Tabulating, proses memasukan atau memindahkan data/jawaban masing-masing responden ke dalam tabel pengolahan data, sehingga akan diperoleh skor total jawaban responden pada masing-masing variabel. Hal ini dilakukan untuk mempermudah transformasi data pada saat analsis data.

\section{HASIL DAN PEMBAHASAN}

\section{A. Tingkat Capaian Faktor Sosial $\left(\mathbf{X}_{1}\right)$}

Hasil rekapitulasi capaian faktor sosial dari lima (5) indikator : umur wanita tani, pelatihan, pengalaman berusahatani, motivasi berusahatani, dan tingkat kekosmopolitan diperoleh hasil tingkat capaian 54,00 \% termasuk kriteria cukup tinggi. Hasil rekapitulasi disampaikan pada Tabel 1.

Tabel 1. Tingkat Capaian Faktor Sosial $\left(\mathrm{X}_{1}\right)$

\begin{tabular}{rlcccr}
\hline No & \multicolumn{1}{c}{ Indikator } & Notasi & $\begin{array}{c}\text { Skor } \\
\text { Capaian }\end{array}$ & $\begin{array}{c}\text { Skor } \\
\text { Harapan }\end{array}$ & $\begin{array}{c}\text { Tingkat Capaian } \\
(\%)\end{array}$ \\
\hline 1 & Umur & $\mathrm{X}_{11}$ & 189 & 250 & 75,60 \\
2 & Pelatihan & $\mathrm{X}_{12}$ & 67 & 250 & 26,80 \\
3 & Pengalaman & $\mathrm{X}_{13}$ & 178 & 250 & 71,20 \\
4 & Motivasi Berusahatani & $\mathrm{X}_{14}$ & 133 & 250 & 53,20 \\
5 & Tingkat Kekosmopolitan & $\mathrm{X}_{15}$ & 108 & 250 & 53,20 \\
\hline Jumlah & $\mathrm{X}_{1}$ & 675 & \multicolumn{2}{c}{ Kriteria : Cukup Tinggi } \\
\hline
\end{tabular}

Tabel 1. Menunjukan dari 5 faktor sosial kriteria yang terendah adalah indikator Pelatihan $(26,80 \%)$ dengan kriteria cukup tinggi. Pelatihan responden didominasi oleh jarang dilakukannya pelatihan. Indikator pelatihan ini sangat mempengaruhi pelaksanaan usahatani jahe merah dengan faktor ekonomi baik dalam memutuskan suatu rencana apapun. Megantisipasi kelemahan pelatihan dapat dilakukan dengan mengikuti pelatihan-pelatihan dan mengadakan pelatihan secara rutin, dan Tabel 2. Tingkat Capaian Faktor Ekonomi $\left(\mathrm{X}_{2}\right)$ megikuti seminar kursus yang berhubungan dengan usahatani jahe merah.

\section{B. Tingakat Capaian Faktor Ekonomi ( $\left.\mathbf{X}_{2}\right)$}

Hasil rekapitulasi capaian faktor ekonomi dari ke empat (4) indikator : tanggungan keluarga, sumber modal, status kepemilikan lahan, dan pendapatan anggota KWT diperoleh hasil tingkat capaian 73,00\% termasuk kriteria tinggi. Hasil rekapitulasi disampaikan pada Tabel 2.

\begin{tabular}{clcccr}
\hline No & \multicolumn{1}{c}{ Indikator } & Notasi & $\begin{array}{c}\text { Skor } \\
\text { Capaian }\end{array}$ & $\begin{array}{c}\text { Skor } \\
\text { Harapan }\end{array}$ & $\begin{array}{c}\text { Tingkat Capaian } \\
(\%)\end{array}$ \\
\hline 1 & Tanggungan Keluarga & $\mathrm{X}_{21}$ & 206 & 250 & 82,40 \\
2 & Sumber Modal & $\mathrm{X}_{22}$ & 170 & 250 & 68,00 \\
3 & Status Lahan & $\mathrm{X}_{23}$ & 210 & 250 & 84,00 \\
4 & Pendapatan Anggota KWT & $\mathrm{X}_{24}$ & 144 & 250 & 57,60 \\
\hline Jumlah & $\mathrm{X}_{2}$ & 730 & 1000 & 73,00 \\
\hline & & & & Kriteria : Tinggi \\
\hline
\end{tabular}


Capaian faktor ekonomi yang dilakukan responden dalam usahatani jahe merah pada umumnya mempunyai kriteria tinggi. Tetapi pada indikator pendapatan anggota KWT memiliki kriteria cuku tinggi sebesar 57,60\%. Dan mengantisipasi kelemahan pendapatan anggota KWT dapat dilakukan dengan lebih resentatif lagi dalam melakukan pemeliharaan jahe merah supaya produktivitas nya tinggi dan pendapatan pun semakin bertambah.

\section{Tingkat Capaian Partisipasi Anggota KWT (Y)}

Hasil rekapitulasi capaian partisipasi anggota KWT dari delapan (8) indikator : penetapan tujuan, pengambilan keputusan, pemanfaatan hasil, pengawasan jalannya usaha, pelayanan waserda, pelayanan sarana produksi, pelayanan kebutuhan anggota dan kemasyarakatan, pelayanan pemasaran produksi diperoleh hasil tingkat capaian 60,55 \% kriteria cukup tinggi. Dengan begitu capaian skor partisipasi anggota KWT dapat dilihat pada tabel 36 yaitu sebagai berikut.

Tabel 3. Tingkat Capaian Faktor Partisipasi Anggota KWT (Y)

\begin{tabular}{clcccc}
\hline No & \multicolumn{1}{c}{ Indikator } & Notasi & $\begin{array}{c}\text { Skor } \\
\text { Capaian }\end{array}$ & $\begin{array}{c}\text { Skor } \\
\text { Harapan }\end{array}$ & $\begin{array}{c}\text { Tingkat } \\
\text { Capaian } \\
(\%)\end{array}$ \\
\hline 1 & Penetapan Tujuan & $\mathrm{Y}_{1}$ & 138 & 250 & 55,20 \\
2 & Pengambilan Keputusan & $\mathrm{Y}_{2}$ & 225 & 250 & 90,00 \\
3 & Frekuensi Kehadiran & $\mathrm{Y}_{3}$ & 123 & 250 & 49,20 \\
4 & Pengawasan Jalannya Usaha & $\mathrm{Y}_{4}$ & 90 & 250 & 36,00 \\
5 & Pelayanan Waserda & $\mathrm{Y}_{5}$ & 149 & 250 & 59,60 \\
6 & Pelayanan Sarana Produksi & $\mathrm{Y}_{6}$ & 158 & 250 & 63,20 \\
7 & Pelayanan Kebuthan & $\mathrm{Y}_{7}$ & 145 & 250 & 58,00 \\
8 & Pelayanan Pemasaran & $\mathrm{Y}_{8}$ & 183 & 250 & 73,20 \\
\hline Jumlah & $\mathrm{Y}^{2}$ & 1211 & 2000 & 60,55 \\
\hline & & & & \multicolumn{2}{c}{ Kriteria : Cukup Tinggi }
\end{tabular}

Berdasarkan tabel 36 diatas, bahwa dari hasil penelitian terlihat bahwa tingkat partisipasi anggota kelompok wanita tani mulai dari penetapan tujuan sampai pelayanan pemasaran produksi tergolong cukup tinggi $(60,55 \%)$, hanya saja pada indikator pengawasan jalannya usaha berada pada kategori sedang $(36,00 \%)$. Indikator pengambilan keputusan berada pada kategori sangat tinggi $(90,00 \%)$ dan sangat penting dalam meningkatkan kerjasama dan pendapatan usahatani jahe merah.

\section{Pengujian Variabel-variabel Hipotesis Penelitian}

Pengujian hipotesis penelitian ini menggunakan analisis jalur (Path Analisis).
Teknik analisis jalur ini digunakan untuk menguji besarnya sumbangan (kontribusi) langsung dan tidak langsung yang diwujudkan oleh koefisien jalur pada setiap diagram jalur dari hubungan kausal antar variabel faktor sosial $\left(\mathrm{X}_{1}\right)$, faktor ekonomi $\left(\mathrm{X}_{2}\right)$ terhadap partisipasi anggota KWT (Y).

\section{E. Uji Validitas Variabel Penelitian}

Uji validitas dilakukan untuk mengetahui tingkat kevalidan dari instrumen (kuesioner) yang digunakan dalam pengumpulan data yang diperoleh dengan cara mengkorelasi setiap skor dan variabel jawaban responden dengan total skor masing-masing variabel, kemudian hasil korelasi dibandingkan dengan nilai kritis pada taraf signifikan 0,05 dan 0,01 . Tinggi 
rendahnya validitas instrumen akan tidak menyimpang dari gambaran tentang menunjukan sejauh mana data yang terkumpul variabel yang dimaksud.

Tabel 4. Uji Validitas Faktor Sosial $\left(\mathrm{X}_{1}\right)$, Faktor Ekonomi $\left(\mathrm{X}_{2}\right)$ dan Partisipasi Anggota KWT (Y) Correlations

\begin{tabular}{|ll|r|r|r|}
\hline & \multicolumn{2}{|c|}{ Faktor Sosial } & Faktor Ekonomi & Partisipasi Anggota KWT \\
\hline Faktor Sosial & Pearson Correlation & 1 &, 836 &, 910 \\
& Sig. (2-tailed) & &, 000 &, 000 \\
& $\mathrm{~N}$ & 50 & 50 & 50 \\
\hline Faktor Ekonomi & Pearson Correlation &, 836 & 1 &, 838 \\
& Sig. (2-tailed) &, 000 &, 000 \\
& $\mathrm{~N}$ & 50 & 50 & 50 \\
\hline Partisipasi & Pearson Correlation &, 910 &, 838 & 1 \\
Anggota KWT & Sig. (2-tailed) &, 000 &, 000 & 50 \\
& $\mathrm{~N}$ & 50 & 50 \\
\hline
\end{tabular}

Dari output yang dihasilkan korelasi antar variabel dengan nilai total masing-masing signifikan pada nilai kritik 0,01 .

\section{F. Uji Reliabiltas Variabel Penelitian}

Uji reliabilitas digunakan untuk mengetahui adanya konsistensi alat ukur dalam penggunannya, atau dengan kata lain alat ukur tersebut mempunyai hasil yang konsisten apabila digunakan berkali-kali pada waktu yang berbeda. Menurut Arikunto (Arikunto, 2006), penggunaan teknik Alpha-Cronbach akan menunjukan bahwa suatu instrumen dapat dikatakan handal (reliabel) bila memiliki koefisien reliabilitas atau alpha sebesar 0,6 atau lebih. Penggunaan teknik alpha ini tidak membagi item/atribut menjadi dua bagian seperti layaknya metode Gutman Split-Half, tetapi ia mengkoreksikan semua item secara langsung.

\section{a) Uji Reliabilitas Variabel $\mathrm{X}_{1}$ (Faktor Sosial)}

Hasil analisis reliabilitas variabel $\mathrm{X}_{1}$ (Faktor Sosial) dengan SPSS versi 23 ditampilkan pada Tabel 5.

Tabel 5. Statistik Realiabilitas Faktor Sosial $\left(\mathrm{X}_{1}\right)$

Reliability Statistics

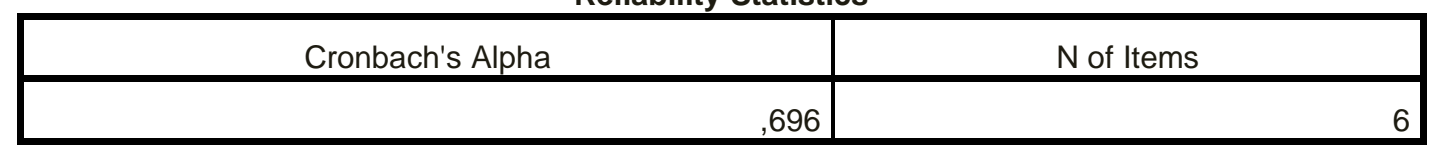

Karena nilai Alpha $=0,696>0,6$, maka instrumen penelitian $\mathrm{X}_{1}$ (Faktor Sosial) sudah valid dan reliable.

\section{b) Uji Reliabilitas Variabel $\mathbf{X}_{2}$ (Faktor Ekonomi)}

Hasil analisis reliabilitas variabel $\mathrm{X}_{2}$ (Faktor Ekonomi) dengan SPSS versi 23 ditampilkan pada Tabel 6.

Tabel 6. Statistik Reliabilitas Faktor Ekonomi $\left(\mathrm{X}_{2}\right)$

Reliability Statistics

\begin{tabular}{|c|c|}
\hline Cronbach's Alpha & $\mathrm{N}$ of Items \\
\hline ,646 & 5 \\
\hline
\end{tabular}

Karena nilai Alpha $=0,646>0,6$, maka instrumen penelitian $\mathrm{X}_{2}$ (Faktor Ekonomi) sudah valid dan reliable. c) Uji Reliabilitas Variabel Y (Partisipasi Anggota KWT)

Hasil analisis reliabilitas variabel $\mathrm{Y}$ (Partisipasi Anggota KWT) dengan SPSS versi 23 ditampilkan pada Tabel 7. 
Tabel 7. Statistik Reliabilitas Variabel (Y)

Reliability Statistics

\begin{tabular}{|c|c|}
\hline Cronbach's Alpha & $\mathrm{N}$ of Items \\
\hline ,729 & \\
\hline
\end{tabular}

Karena nilai Alpha $=0,729>0,6$, maka instrumen penelitian Y (Partisipasi Anggota KWT) sudah valid dan reliable.

\section{G. Pengujian Hipotesis Penelitian}

Hasil analisis hubungan variabel Faktor Sosial $\left(\mathrm{X}_{1}\right)$, Faktor Ekonomi $\left(\mathrm{X}_{2}\right)$ terhadap Partisipasi Anggota KWT (Y) untuk Model Summary dapat dilihat dilampiran. Berdasarkan data pada tabel (Model Summary) ada pengaruh signifikan antara variabel Faktor Sosial $\left(\mathrm{X}_{1}\right)$, Faktor Ekonomi $\left(\mathrm{X}_{2}\right)$ terhadap Partisipasi Anggota KWT (Y), dengan indikator :

1) Nilai R (koefisien korelasi berganda) merupakan derajat keeratan hubungan antara peubah Faktor Sosial $\left(\mathrm{X}_{1}\right)$ dan Faktor Ekonomi $\left(\mathrm{X}_{2}\right)$ secara simultan terhadap peubah terikat Partisipasi Anggota KWT (Y). Hasil Analisis pada Model Summary menunjukan nilai $\mathrm{R}=0,924$ hal ini menunjukan hubungan yang sangat erat (reliabel) antara Faktor Sosial $\left(\mathrm{X}_{1}\right)$ dan Faktor Ekonomi $\left(\mathrm{X}_{2}\right)$ secara simultan terhadap peubah terikat Partisipasi Anggota KWT (Y) artinya jika peubah $\mathrm{X}_{1}$ dan peubah $\mathrm{X}_{2}$ meningkat maka peubah terikat Y juga akan meningkat (korelasi positif). Berdasarkan Husain Umar (2008) keeratan hubungan ditentukan seperti pada Tabel 8 .

Tabel 8. Nilai R (Korelasi) dan keeratan Hubungan

\begin{tabular}{cl}
\hline Nilai R Korelasi & \multicolumn{1}{c}{ Kriteria Hubungan } \\
\hline Kurang dari 0,2 & Hubungan yang sangat kecil dan bias diabaikan \\
$0,20-<0,40$ & Hubungan yang sangat kecil (tidak erat) \\
$0,40-<0,70$ & Hubungan yang cukup erat \\
$0,70-<0,90$ & Hubungan yang erat (reliabel) \\
$0,90-<1,00$ & Hubungan yang sangat erat (sangat reliabel) \\
1,00 & Hubungan yang sempurna \\
\hline
\end{tabular}

2) Nilai $R$ square $\left(R^{2}\right)$ juga disebut sebagai koefisien determinasi gunanya untuk mengetahui besarnya kontribusi peubah bebas $\left(\mathrm{X}_{1}\right.$ dan $\left.\mathrm{X}_{2}\right)$ secara serempak didalam menjelaskan peubah terikat (Y). R Square juga dapat menunjukan ragam naik atau turunnya peubah terikat (Y) yang diterangkan oleh pengaruh linier peubah bebas $\left(\mathrm{X}_{1}\right.$ dan $\left.\mathrm{X}_{2}\right)$. Ukuran nilai $\mathrm{R}$ Square adalah $0 \leq \mathrm{R}^{2} \leq 1$, artinya semakin mendekati angka satu berarti garis regresi yang terbentuk dapat meramalkan peubah terikat (Y) secara lebih baik menuju kesempurnaan (model fit). Dalam model summary nilai $\mathrm{R}^{2}$ sebesar 0,850. Dapat diartikan bahwa peubah bebas dalam hal ini Faktor Sosial dan Faktor Ekonomi secara bersama-sama menjelaskan peubah Partisiapsi Anggota KWT sebesar 85,0 \%, sedangkan sisanya $15,0 \%$ dijelaskan oleh peubah lain. Semakin besar $\mathrm{R}^{2}$ semakin menunjukan ketepatan model yang telah disusun (model yang dimaksud adalah model teori penelitian ini).

Matriks korelasi Faktor Sosial dan Faktor Ekonomi terhadap Partisipasi Anggota KWT disajikan pada Tabel 9. 
Tabel 9. Matriks Korelasi Variabel Faktor Sosial dan Faktor Ekonomi terhadap Partisipasi Anggota KWT

\begin{tabular}{cccc}
\hline & $\begin{array}{c}\mathbf{X}_{\mathbf{1}} \\
(\text { Faktor Sosial) }\end{array}$ & $\begin{array}{c}\mathbf{X}_{\mathbf{2}} \\
\text { (Faktor } \\
\text { Ekonomi) }\end{array}$ & $\begin{array}{c}\mathbf{Y} \\
\text { (Partisipasi } \\
\text { Anggota KWT) }\end{array}$ \\
\hline $\mathbf{X}_{\mathbf{1}}$ & 1,000 & 0,836 & 0,910 \\
$\mathbf{X}_{\mathbf{2}}$ & 0,836 & 1,000 & 0,838 \\
$\mathbf{Y}$ & 0,910 & 0,838 & 1,000 \\
\hline
\end{tabular}

Koefisien jalur untuk Faktor Sosial dan Faktor Ekonomi terhadap Partisipasi Anggota KWT, dapat dilihat dilampiran. Secara matriks koefisien jalur untuk faktor sosial dan faktor ekonomi terhadap partisipasi anggota KWT adalah sebagai berikut :

$\left[\begin{array}{l}\text { pyx } 1 \\ \text { pyx } 2\end{array}\right]=\left[\begin{array}{l}0,692 \\ 0,263\end{array}\right]$

Dapat dilhat pada lampiran dari model summery terlihat kalau $\mathrm{R}$ Square atau $\mathrm{R}^{2}$ atau koefisien determinasi adalah 0,850 . Dari $\mathrm{R}$ Square tersebut dapat dihitung koefisien jalur variabel lain diluar model yakni $\mathrm{py}_{\epsilon}$ dengan rumus :

$\mathrm{py}_{\epsilon}=\sqrt{1-R \frac{2}{z y x}}$

Secara manual koefisien jalur diuji dengan statistik uji t dengan derajat bebas 47 pada titik kritis adalah 1,67793. Dengan kembali menggunakan output SPSS, di tabel Coefficient*, pada kolom sig dan $\mathrm{t}$ dipakai untuk menguji koefisien jalur untuk pengujiannya dilakukan sebagai berikut :

1) Pengujian koefisien jalur faktor sosial $X_{1}$ terhadap partisipasi anggota KWT Y $\left(\mathrm{p}_{\mathrm{yx} 1}\right)$.

$$
\begin{aligned}
& \mathrm{H}_{0}: \mathrm{p}_{\mathrm{yx} 1}=0 \\
& \mathrm{H}_{1}: \mathrm{p}_{\mathrm{yx} 1} \neq 0
\end{aligned}
$$

Dapat dilihat pada $\mathrm{p}$-value (kolom Sig) $=$ 0,000 yang lebih kecil dari 0,05 atau pada kolom $t_{\text {hitung }}=13,884$ yang lebih besar dari titik kritis 1,67793. Dengan demikian $\mathrm{H}_{0}$ ditolak.

2) Pengujian koefisien jalur faktor ekonomi terhadap partisipasi anggota KWT $\left(\mathrm{p}_{\mathrm{yx} 2}\right)$.

$$
\begin{aligned}
& \mathrm{H}_{0}: \mathrm{p}_{\mathrm{yx} 2}=0 \\
& \mathrm{H}_{1}: \mathrm{p}_{\mathrm{y} \times 2}=0
\end{aligned}
$$

Dapat dilihat pada p-value (kolom Sig) $=$ 0,000 yang lebih kecil dari 0,05 atau pada kolom $t_{\text {hitung }}=5,275$ yang lebih besar dari dari titik kritis 1,67793. Dengan demikian $\mathrm{H}_{0}$ ditolak.

Dari hasil pengujian koefisien jalur diperoleh keterangan obyektif, bahwa koefisien jalur dari $\mathrm{X}_{1}$ ke $\mathrm{Y}$ dan $\mathrm{X}_{2}$ ke $\mathrm{Y}$ kedua-duannya secara statistik adalah bermakna ( thitung $_{\text {) diatas }}$ $t_{\text {tabel }}$ dan $\mathrm{p}$-value dibawah 0,05). Sehingga dapat disimpulkan bahwa faktor sosial $\left(\mathrm{X}_{1}\right)$, dan faktor sosial $\left(\mathrm{X}_{2}\right)$ mempunyai pengaruh positif terhadap partisipasi anggota KWT (Y).

Diagram jalur ini terdapat dua buah variabel eksogen $\mathrm{X}_{1}$ (Faktor Sosial) dan $\mathrm{X}_{2}$ (Faktor Ekonomi), serta satu variabel endogen, yaitu Y (Partisipasi Anggota KWT).

Bentuk persamaan strukturalnya untuk diagram jalur ini adalah :

$Y=0,692 X_{1}+0,263 X_{2}+€$

Koefisien Determinasi ( $\mathrm{R}$ Square) atau $\mathrm{R}^{2}$ adalah 0,850 .

py€ $=\sqrt{1-0,850=} \sqrt{0,150}=0,3873$, maka :

$Y=0,692 X_{1}+0,263 X_{2}+0,387$

Besarnya pengaruh secara Proposional Variabel $\mathrm{X}_{1}$ (Faktor Sosial) dan Variabel $\mathrm{X}_{2}$ (Faktor Ekonomi) terhadap Y (Partisiapsi Anggota KWT) :

a) Pengaruh $X_{1}$ (Faktor Sosial)

Pengaruh Langsung : $\mathrm{p}_{\mathrm{yx} 1} \times \mathrm{p}_{\mathrm{yx} 1}$

$$
:(0,692)(0,692)=0,4788
$$

Pengaruh Tidak Langsung : $p_{y x 1} \times r_{x 1 \times 2} \times p_{y \times 2}$

$$
\begin{aligned}
& : 0,692 \times 0,836 \times 0,263 \\
& : 0,1521
\end{aligned}
$$

Pengaruh $\mathrm{X}_{1}$ ke $\mathrm{Y}$ secara total : $0,4788+$ $0,1521=0,6309$ 
b) Pengaruh $\mathrm{X}_{2}$ (Faktor Ekonomi)

Pengaruh Langsung : $p_{y \times 2} \times p_{y \times 22}$

$$
: 0,263 \times 0,263=0,0692
$$

Pengaruh Tidak Langsung: $\mathrm{p}_{\mathrm{yx} 2} \times \mathrm{r}_{\mathrm{x} 1 \times 2} \times \mathrm{p}_{\mathrm{yx} 1}$

: $0,263 \times 0,836 \times 0,692$

: 0,1521

Pengaruh $\mathrm{X}_{2}$ ke $\mathrm{Y}$ secara total

: $0,0692+0,1521=0,2213$

Pengaruh gabungan oleh $\mathrm{X}_{1}$ dan $\mathrm{X}_{2}$ ke $\mathrm{Y}$ adalah $0,6302+0,2213=0,8515$ yang tidak lain adalah besarnya $\mathrm{R}^{2} \mathrm{Y}(\mathrm{KD})=0,850$ dapat dilihat pada lampiran. Model summary faktor sosial dan faktor ekonomi terhadap partisipasi anggota KWT.

Atas dasar perhitungan diatas diartikan hal-hal sebagai berikut :

1) Kekuatan $X_{1}$ (Faktor Sosial) yang secara langsung menentukan perubahanperubahan Y (Partisipasi Anggota KWT) adalah $47,88 \%(0,4788)$, dan yang melalui hubungan dengan $\mathrm{X}_{2}$ (Faktor Ekonomi) sebesar 15,21 \% (0,1521). Dengan demikian, secara total $\mathrm{X}_{1}$ (Faktor Sosial) menentukan perubahan-perubahan $\mathrm{Y}$ (Partisipasi Anggota KWT) sebesar 63,09 $\%$.

2) Secara total $22,13 \%(0,2213)$ dari perubahan $\mathrm{Y}$ merupakan pengaruh $\mathrm{X}_{2}$ (Faktor Sosial), dengan perincian 6,62\% $(0,0662)$ adalah pengaruh langsung dan $15.21 \%$ melalui hubungannya dengan $\mathrm{X}_{1}$ (Faktor Sosial).

3) $X_{1}$ (Faktor Sosial) dan $X_{2}$ (Faktor Ekonomi) secara bersama-sama tidak mempengaruhi Y (Partisipasi Anggota KWT) sebesar 63,09\%+22,13\%= $85,22 \%\left(\mathrm{R}^{2}=0,696\right)$. Besarnya pengaruh secara proposional yang disebabkan oleh variabel lain seperti faktor lingkungan diluar variabel $\mathrm{X}$ dan $\mathrm{Y}$, dinyatakan oleh $\mathrm{p}_{\mathrm{y} \epsilon}=\sqrt{1-0,850=} \sqrt{0,150}=0,387$ atau sebesar $38,7 \%$.

4) Besarnya pengaruh yang diterima oleh $Y$ (Partisipasi Anggota KWT) dari $\mathrm{X}_{1}$ (Faktor
Sosial) dan $\mathrm{X}_{2}$ (Faktor Ekonomi) dan dari semua variabel diluar $\mathrm{X}_{1}$ dan $\mathrm{X}_{2}$ (yang dinyatakan oleh variabel residu $€$ ) adalah $\mathrm{R}^{2} \mathrm{Y}(\mathrm{TD})+\mathrm{p}^{2}{ }_{\mathrm{ye}}=85,22 \%+14,78 \%=$ $100 \%$

Guna melihat pengaruh variabel atau konstruk mana yang lebih besar, dapat dilihat pada uji statistik $t$ yang terdapat pada tabel Coefficients $^{\mathrm{a}}$ di output hasil SPSS. Variabel yang memiliki hasil uji $t$ yang lebih besar merupakan variabel yang memiliki pengaruh yang lebih besar dibanding variabel lainnya. Dapat dilihat pada lampiran. Coefficients ${ }^{\mathrm{a}}$ Faktor Sosial dan Faktor Ekonomi terhadap Partisipasi Anggota KWT.

Coefficients ${ }^{\mathrm{a}}$ membuktikan bahwa variabel Faktor Sosial $\left(\mathrm{X}_{1}\right)$ memiliki hasil $\mathrm{t}_{\text {hitung }}(13,884)$ lebih besar apabila dibandingkan dengan $t_{\text {hitung }}$ variabel Faktor Ekonomi $\left(\mathrm{X}_{2}\right)(5,275)$, jadi bisa disimpulkan bahwa Faktor Sosial lebih besar pengaruhnya dari pada Faktor Ekonomi terhadap variabel dependen, itu disebabkan karena faktor sosial berhubungan langsung dengan partisipasi anggota KWT. Beda dengan variabel faktor ekonomi tidak secara langsung berhubungan dengan partisipasi anggota KWT. Tidak semua orang yang besarnya pengaruh secara Proposional Variabel $\mathrm{X}_{1}$ (Faktor Sosial) dan Variabel $\mathrm{X}_{2}$ (Faktor Ekonomi) terhadap Y (Partisiapsi Anggota KWT) :

c) Pengaruh $X_{1}$ (Faktor Sosial)

Pengaruh Langsung : $\mathrm{p}_{\mathrm{yx} 1} \times \mathrm{p}_{\mathrm{yx} 1}$

$:(0,692)(0,692)=0,4788$

Pengaruh Tidak Langsung : $p_{\mathrm{yx} 1} \times \mathrm{r}_{\mathrm{x} 1 \times 2} \times \mathrm{p}_{\mathrm{yx} 2}$

: $0,692 \times 0,836 \times 0,263$

$: 0,1521$

Pengaruh $\mathrm{X}_{1}$ ke $\mathrm{Y}$ secara total

$: 0,4788+0,1521=0,6309$

d) Pengaruh $X_{2}$ (Faktor Ekonomi)

Pengaruh Langsung : $\mathrm{p}_{\mathrm{yx} 2} \times \mathrm{p}_{\mathrm{yx} 22}$ : $0,263 \times 0,263=0,0692$

Pengaruh Tidak Langsung $\quad: \mathrm{p}_{\mathrm{yx} 2} \times \mathrm{r}_{\mathrm{x} 1 \times 2} \times \mathrm{p}_{\mathrm{yx} 1}$ $: 0,263 \times 0,836 \times 0,692$

: 0,1521

Pengaruh $\mathrm{X}_{2}$ ke $\mathrm{Y}$ secara total 
$: 0,0692+0,1521=0,2213$

Pengaruh gabungan oleh $\mathrm{X}_{1}$ dan $\mathrm{X}_{2}$ ke $\mathrm{Y}$ adalah $0,6302+0,2213=0,8515$ yang tidak lain adalah besarnya $\mathrm{R}^{2} \mathrm{Y}(\mathrm{KD})=0,850$ dapat dilihat pada lampiran. Model summary faktor sosial dan faktor ekonomi terhadap partisipasi anggota KWT.

Atas dasar perhitungan diatas diartikan hal-hal sebagai berikut :

1) Kekuatan $X_{1}$ (Faktor Sosial) yang secara langsung menentukan perubahan-perubahan Y (Partisipasi Anggota KWT) adalah 47,88 $\%(0,4788)$, dan yang melalui hubungan dengan $\mathrm{X}_{2}$ (Faktor Ekonomi) sebesar 15,21 $\%(0,1521)$. Dengan demikian, secara total $\mathrm{X}_{1}$ (Faktor Sosial) menentukan perubahanperubahan Y (Partisipasi Anggota KWT) sebesar 63,09\%.

2) Secara total $22,13 \%(0,2213)$ dari perubahan $\mathrm{Y}$ merupakan pengaruh $\mathrm{X}_{2}$ (Faktor Sosial), dengan perincian 6,62\% $(0,0662)$ adalah pengaruh langsung dan $15.21 \%$ melalui hubungannya dengan $\mathrm{X}_{1}$ (Faktor Sosial).

3) $X_{1}$ (Faktor Sosial) dan $X_{2}$ (Faktor Ekonomi) secara bersama-sama tidak mempengaruhi $\mathrm{Y}$ (Partisipasi Anggota KWT) sebesar 63,09\%+22,13\%= $85,22 \%\left(\mathrm{R}^{2}=0,696\right)$. Besarnya pengaruh secara proposional yang disebabkan oleh variabel lain seperti faktor lingkungan diluar variabel $\mathrm{X}$ dan $\mathrm{Y}$, dinyatakan oleh $p_{\mathrm{y} \epsilon}=\sqrt{1-0,850=} \sqrt{0,150}=0,387$ atau sebesar 38,7\%.

4) Besarnya pengaruh yang diterima oleh $Y$ (Partisipasi Anggota KWT) dari $\mathrm{X}_{1}$ (Faktor Sosial) dan $\mathrm{X}_{2}$ (Faktor Ekonomi) dan dari semua variabel diluar $\mathrm{X}_{1}$ dan $\mathrm{X}_{2}$ (yang dinyatakan oleh variabel residu $€$ ) adalah $\mathrm{R}^{2} \mathrm{Y}(\mathrm{TD})+\mathrm{p}_{\mathrm{y} \epsilon}^{2}=85,22 \%+14,78 \%=$ $100 \%$

Guna melihat pengaruh variabel atau konstruk mana yang lebih besar, dapat dilihat pada uji statistik $t$ yang terdapat pada tabel Coefficients $^{\mathrm{a}}$ di output hasil SPSS. Variabel yang memiliki hasil uji $t$ yang lebih besar merupakan variabel yang memiliki pengaruh yang lebih besar dibanding variabel lainnya. Dapat dilihat pada lampiran. Coefficients ${ }^{\mathrm{a}}$ Faktor Sosial dan Faktor Ekonomi terhadap Partisipasi Anggota KWT.

Coefficients ${ }^{\mathrm{a}}$ membuktikan bahwa variabel Faktor Sosial $\left(\mathrm{X}_{1}\right)$ memiliki hasil thitung $(13,884)$ lebih besar apabila dibandingkan dengan $t_{\text {hitung }}$ variabel Faktor Ekonomi $\left(\mathrm{X}_{2}\right)(5,275)$, jadi bisa disimpulkan bahwa Faktor Sosial lebih besar pengaruhnya dari pada Faktor Ekonomi terhadap variabel dependen, itu disebabkan karena faktor sosial berhubungan langsung dengan partisipasi anggota KWT. Beda dengan variabel faktor ekonomi tidak secara langsung berhubungan dengan partisipasi anggota KWT.

Tidak semua orang yang mempunyai modal akan dibelanjakan untuk saprotan, membudidayakan dengan benar sesuai dengan yang dianjurkan. Karena selain mempunyai uang, mereka melaksanakan usahatani juga dipengaruhi oleh pengalaman pengetahuan, kebiasaan dan lain-lain. Kenyataannya dari hasil perhitungan pengaruh total variabel $\mathrm{X}_{1}$ (Faktor Sosial) terhadap variabel dependen $\mathrm{Y}$ (Partisipasi Anggata KWT) adalah sebesar 0,6309 atau $63,09 \%$, sedangkan pengaruh total variabel $\mathrm{X}_{2}$ Faktor Ekonomi terhadap variabel dependen adalah sebesar 0,2213 atau 22,13\%.

\section{KESIMPULAN}

Berdasarkan hasil penelitian dan pembahasan, maka dapat disimpulkan sebagai berikut:

1. Faktor sosial berpengaruh terhadap partisispasi anggota KWT dengan demikian faktor sosial berpengaruh langsung sebesar $47,88 \%$ dan pengaruh melalui hubungan korelatif dengan faktor ekonomi $15,21 \%$ sehingga pengaruh total faktor sosial terhadap partisipasi anggota KWT sebesar $63,09 \%$.

2. Faktor Ekonomi berpengaruh terhadap partisipasi anggota KWT. Faktor ekonomi berpengaruh langsung sebesar $69,2 \%$ dan pengaruh melalui hubungan korelatif 
dengan faktor sosial sebesar 15,21 \% sehingga pengaruh total faktor ekonomi terhadap partisipasi anggota KWT sebesar $22,13 \%$.

3. Faktor sosial dan faktor ekonomi secara simultan berpengaruh signifikan terhadap partisipasi anggota KWT sebesar 85,22\%. Sisanya sebesar $14,78 \%$ dipengaruhi oleh faktor lain yang tidak diteliti dalam penelitian ini.

\section{DAFTAR PUSTAKA}

Alam, K.S., L. Hakim, and A.R. Razak. 2019. Pengaruh Partisipasi Kelompok Wanita Tani Terhadap Peningkatan Perekonomian Keluarga Di Kelurahan Appanang Kabupaten Soppeng. Kolaborasi J. Adm. Publik 5(3): 371-387. doi: https://doi.org/10.26618/kjap.v5i3.2940.

Arikunto, S. 2006. Prosedur Penelitian Pendekatan Praktik (Edisi Revisi VI). Rineka Cipta.

Marzuki, S. 2001. Pekerja Wanita Pada Agroindustri Pangan di Pedesaan Kabupaten Kerinci Provinsi Jambi. J. Penelit. UNIB 7(2): 210-225.

Nursal, W. 2006. Bioaktivitas Ekstrak Jahe (Zingiber officinale Roxb.) dalam Menghambat Pertumbuhan Koloni Bakteri Escherichia coli dan Bacillus subtilis. J. Biog. 2(2): 64-66.

Pertanian, K. 2008. Budidaya Organik Tanaman Jahe. Balai Penelit. Tanam. Obat dan Aromat.

Siagian, V.J. 2014. Outlook Komoditi Jahe. Pus. Data dan Sist. Inf. Pertan. Kementeri. Pertan.

Sukirno, S. 2012. Mikro Ekonomi Edisi Ketiga. Jakarta. 